\title{
Bir Kuşak Bir Yol Projesinin Azerbaycan, Kazakistan ve Türkiye'ye Etkisi
}

\author{
DOI: 10.26466/opus.774914
}

*

\section{Serdar Yilmaz *}

* Dr. Öğretim Üyesi, Muğla Sıtkı Koçman Üni., Siyaset Bilimi ve Uluslararası İlişkiler Bölümü E-Posta: $\underline{\text { serdaryilmaz@mu.edu.tr }}$

ORCID: 0000-0003-3400-3392

\section{Öz}

Asya kıtasını en önemli aktörlerden biri olan Çin Halk Cumhuriyeti'nin, sahip olduğu jeostratejik ve jeoekonomik avantajları ile 21 yüzyılın küresel hegemonu olmak için sürdürülebilir adımlar attığı görülmektedir. Bu adımlardan en önemlisi ise İpek Yolu olarak bilinen ve çok uzun bir süre ticaretin kalbi olan güzergâhları modern anlamda şekillendiren ve yeni bir düzen inşasının ilk adımı olan BİR KUŞAK BIR YOL (OBOR) projesidir. OBOR projesi ile bölgesel bütünleşmelerin teşvik edilmesi, Çin ve projeye ortak olan diğer ülkeler arasındaki ekonomik, kültürel ve sosyal bağlarm güçlenmesi, yeni işbirliği platformlarının oluşturulması, Çin için gerekli olan enerji arz güvenliğinin tesis edilmesi hedeflenmektedir. Asya, Avrupa ve Afrika kıtalarını deniz ve kara yoluyla birbirine bağlamak isteyen Çin, birçok ulusal ve uluslararası kurumları kullanarak büyük miktarlarda hibe ve kredi vermektedir. Üç ülkeyi kapsayan ve vaka incelemesine dayanan bu çalışma önemli bir iddia ortaya atmıştır. OBOR projesi ile çalışmada yer verilen Azerbeycan, Kazakistan ve Türkiye için firsatlar ve avantajlar oluşabileceği gibi Çin'e her geçen gün artan finansman bağımlılı̆̆ı da yaşanacaktır. Bu iddianın doğrulanması için hem üç ülke ile Çin arasındaki ticaret hacmine hem de üç ülkenin OBOR projesi vesilesiyle Çin devletine olan borcuna bakılmıştır. Çin devleti, OBOR projesini geliştirmek ve daha genişletmek için Türk devletleri üzerinde hangi stratejileri kullandığı sorusuna cevap aranmıştır.

Anahtar Kelimeler: $\quad$ OBOR, Çin, Azerbaycan, Kazakistan, Türkiye 


\title{
The Effect of One Belt One Road Project on Azerbaijan, Kazakhstan and Turkey
}

\begin{abstract}
It is seen that the People's Republic of China, one of the most important actors in the Asian continent, has taken sustainable steps to become the global hegemony of the 21st century with its geostrategic and geoeconomic advantages. The most substantial of these steps is the One Belt One Road (OBOR) project, known as the Silk Road, which has shaped trade routes in a modern sense for a long time. The OBOR project aims to promote regional integration, strengthen economic, cultural and social ties between China and other partner countries, base new platforms of cooperation, and establish energy supply security for China. China desires to connect Asia, Europe and Africa continents by sea and land, thus provides large amounts of grants and loans by cooperating with many national and international institutions. This study, which covers three countries, is based on case studies research method and makes an important claim. OBOR project will both provide opportunities and advantages for Azerbaijan, Kazakhstan and Turkey and it may create financial dependency of the three countries on China. In order to verify this claim, both the trade volume between the three countries and China and the debt of these countries to China through the OBOR project were examined. The study tried to seek an answer the question of what strategies China has used on the Turkish states in order to develop and expand the $O B O R$ project in the current period.
\end{abstract}

Keywords: OBOR, China, Azerbaijan, Kazakhstan, Turkey 


\section{Giriş}

7 Eylül 2013 tarihinde Kazakistan'da ve akabinde 3 Ekim'de Endonezya'da yaptı̆̆ konuşmasında Kara ve Deniz İpek Yolu projelerinden bahseden Çin Halk Cumhuriyeti Devlet Başkanı Xi Jinping, Doğu'da Batı'ya dünyayı adeta bir örümcek ağı gibi saracak Çin projesini dünya gündemine getirmiştir. Her iki projenin de "Kuşak-Yol Girişimi ya da Bir Kuşak Bir Yol" (Belt and Road Initiative-BRI or One Belt One Road-OBOR) projesi olarak adlandırılmasina karar verilmiştir. Kuşak kelimesi projenin karayolları, demir yolları, petrol ve doğalgaz boru hatları ve altyapı yatırımlarını kapsayan Kara güzergâhını oluşturmaktadır. Yol kelimesi ise projenin kapsadığı Deniz yollarını içermektedir.

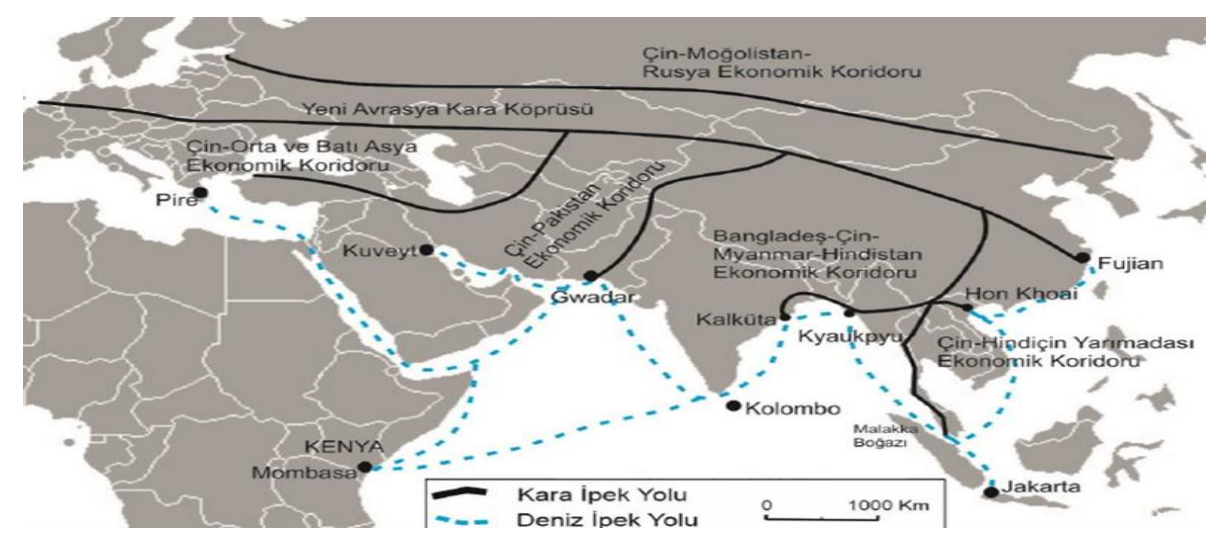

Harita 1: Bir Kuşak Bir Yol Projesi'nin Kara ve Deniz Yolu Ağı (Bülent Güner, “OBOR Girişimi'nin Coğrafyası", Marmara Coŏgrafya Dergisi, sayı 37, Ocak 2018)

Bu koridorların geçiş güzergâhları tek bir rota yerine Asya-Avrupa yönünde çok boyutlu koridorlarla sağlanmaktadır. Kara güzergâhında altı koridor bulunmaktadır. Bunlar: Çin-Moğolistan-Rusya Ekonomik Koridoru, Çin-Orta Asya-Batı Asya Ekonomik Koridoru (Türkiye bu koridorda yer almaktadır), Çin-Hindiçini Yarımadası Ekonomik Koridoru, Yeni Avrasya Kara Köprüsü Ekonomik Koridoru, Bangladeş-Çin-Hindistan-Myanmar Ekonomik Koridoru ve son olarak Çin-Pakistan Ekonomik Koridoru'dur. Projenin Deniz güzergâhında ise sadece Güneydoğu Asya Ülkeleri Birliği (ASEAN) ile değil Güney Asya, Batı Asya, Kuzey Afrika ve Avrupa ekonomilerini de birbirine bağlayacak ekonomik bir koridor amaçlanmaktadır. Bu 
bağlamda OBOR projesi Güney Çin Denizi, Pasifik Okyanusu ve Hint Okyanusunu içeren stratejik bir ekonomik kuşaktır (Yılmaz, 2019, s.12-13).

Bu çalışma, OBOR projesi ile Azerbaycan, Kazakistan ve Türkiye'den oluşan Türk devletlerinin OBOR projesi için ne önem ifade ettiklerine, OBOR girişimi ile bahsedilen Türk devletlerinde hangi projelerin hayata geçirildiğine ve Türk devletlerinin Çin'e karşı artan finansal bağımlılığına değinmektedir. Bu üç devletin seçilmesinin iki nedeni vardır. Birincisi, bu ülkeler Çin ile en fazla doğrudan ticaret yapan Türk ülkeleridir. İkincisi ise bu üç ülke OBOR projesi vesilesiyle Çin'in en fazla yatırım yaptığ 1 Türk ülkeleridir.

\section{Yöntem}

Üç ülkeyi kapsayan ve vaka incelemesine dayanan bu çalışmada, Azerbaycan, Kazakistan ve Türkiye Türkçesi ile yazılan ikincil kaynakların yanı sıra, İngilizce yazılan kaynaklara da başvurulmuştur. Çalışmada önce Azerbaycan sonra Kazakistan ve en sonunda Türkiye Cumhuriyeti'nin OBOR girişimi ile hangi projelere yer verdiği, mevcut ülkelerin Çin için neden önemli olduğu, Çin ile olan ticaret hacimleri ve Çin'e olan olası finansman bağımlılıkları üzerinde durulmuştur. Bu doğrultuda çalışmada 'Borç Diplomasisi' kavramı ve her üç devletinde bu kavramdan etkilenebilme ihtimalleri ortaya konulmuştur. Şimdiye kadar literatürde üç ülkeyi inceleyen bütüncül bir yaklaşımın olmaması çalışmanın önemi ve alan yazımına muhtemel katkısını göstermektedir.

\section{Azerbaycan Cumhuriyeti}

Hazar Denizi'ne kıyısı olan Azerbaycan, doğal kaynaklar konusunda oldukça zengindir. Bu yüzden ülkeye birçok küresel ve bölgesel aktör ilgi duymaktadır. Çin'in Azerbaycan'a olan ilgisinin temeli Çin'den Avrupa'ya uzanan bir demiryolu hattı geliştirmeye çalışmasından kaynaklanmaktadır. Bunun dışında Azerbaycan üzerinden gidecek güzergâh Çin' in mallarının daha güvenli şekilde taşınmasını sağlayacaktır. Ayrıca Azerbaycan'ın sahip olduğu doğal gaz kaynakları ve bölgedeki gücü de Çin'in Azerbaycan'a odaklanmasına vesile olmaktadır. Azerbaycan ile ilgili belirtilmesi gereken bir diğer önemli husus, Azerbaycan'ın OBOR projesinde yeni katılımcıların dahil 
edilme sürecinde önemli ve kararlı bir jeopolitik, politik, kültürel ve ulaşım alanı olması durumudur (Poghasyon, 2018).

\section{OBOR Çerçevesinde Azerbaycan'da Yapılan Projeler}

Bakü-Tiflis-Kars Demiryolu: Türkiye, Azerbaycan, Gürcistan işbirliğinin sonucunda hayata geçen BTK demiryolu söz konusu 3 ülkenin kendi finans gücüyle hayata geçirilmiştir. Azerbaycan devleti Gürcistan'a 220 milyon dolar kredi verilmiştir. BTK'nın 503 kilometresi Azerbaycan'dan geçerken Azerbaycan, güzergâh üzerindeki demiryolunu projeye uygun şekilde düzenlemiştir (Milliyet, 2019).

Bu proje ile Azerbaycan devletinin özellikle yük taşıma konusunda İran devletine olan bağımlılı azalacağı gibi ülke ayrıca bir geçiş ücreti alarak ekonomik çeşitlilik yaratacaktır. Bu proje ile birlikte Azerbaycan'ın ulaştırma sektörü çeşitlendiği için petrole bağımlı olan sanayinin dışındaki alanların da çeşitlenmesi mümkün olacaktır (Dilek, 2017).

Çin'li Yatırımcılar: Çin'in Güney Kafkasya ile ticaretinin yaklaşık \%50'si Azerbaycan'ladır. Azerbaycan'da ticaret, hizmet, sanayi, inşaat ve diğer alanlarda faaliyet gösteren 100'den fazla Çinli şirket bulunmaktadır. Azerbaycan' daki Çinli firmalar, OBOR çerçevesinde yürütülmesi muhtemel projelere ilişkin raporlar hazırlamakta ve bu raporlar çerçevesinde Çinli girişimciler Azerbaycan'a odaklanarak yatırımlarını arttırmaktadırlar (İnan ve Yayloyan, 2019, s. 65-66). 800 milyon dolarlık yatırım şimdiden yapılmıştır. Azerbaycan ise Çin'de 1.7 milyar dolarlık yatırım yapmıştır (Baghirov, 2019). (Çinli yatırımcılarının bu yatırımlarına karşı Azerbaycan, diğer ülkelere kıyasla ticari ve politika odaklı Çin bankalarına geniş faiz oranı ve vergi indirimleri verme konusunda cömert davranmaktadır (Yan, 2017).

Konferanslar: 23 Nisan 2019 tarihinde Bakü Devlet Üniversitesi altındaki Konfüçyüs Enstitüsü ve Anhui Üniversitesi ortaklaşa OBOR girişimin uygulanması üzerine bir seminere ev sahipliği yapmıştır. Ayrıca Konfüçyüs Enstitüsü'nün Azerbaycan'da kurduğu iki üniversite de mevcuttur. Bu kurumlar uzun bir süredir faaliyet göstermekte ve Azerbaycan-Çin ilişkilerinde çoktan önemli bir köprü haline getirmektedirler (Youth Portal, 2019). 
Davos'ta gerçekleştirilen Dünya Ekonomik Forumu'nun OBOR toplant1sina katılan Cumhurbaşkanı Aliyev, Azerbaycan'ın OBOR projesinde iyi bir ortak olacağını söylemiş ve OBOR'a verdiği önemi şu sözleri ile ifade etmiştir:

“Ülkeleri birleştiren herhangi bir ulaşım projesinin jeopolitik temeli olduğuna kesinlikle inanıyorum. Bu projeler jeopolitik durum, istikrar ve öngörü üzerinde olumlu bir etkiye sahiptir. Çünkü bu projeler karşılıklı bağımlılık yaratıyor. Komşularımız olmadan transit ülke olamayız. Komşularımız komşuları olmadan transit ülke olamazlar. Bu nedenle kıtaları, ülkeleri birleştirip daha öngörülebilir bir gelecek yaratıyoruz." (Bizimyol, 2019).

Azerbaycan tarafından ise Haydar Aliyev Merkezinin desteğiyle "Pekin Expo 2019" Botanik Sergisi çerçevesinde Azerbaycan'ın ulusal günü düzenlenmiş ve 4-5 Mayıs 2016 tarihinde Azerbaycan Cumhuriyeti Cumhurbaşkanlığ 1 altında Stratejik Araştırma Merkezi tarafından hazırlanan Çin dilinde “Azerbaycan'ın Gelişim Yolu” başlıklı bir kitap Çin'de sunulmuştur (Beijing, 2019).

Çin'de Azerbaycan Araştırma Merkezinin Kurulması: Çin Lanzhou Üniversitesi Rektörü, Azerbaycan Cumhuriyeti Bilimler Akademisi Üyesi, Üniversiteler Birliği Başkanı, Profesör Yan Chunhua ve Azerbaycan Devlet Petrol ve Sanayi Üniversitesi Rektörü Profesör Mustafa Babanlı, üniversiteler arasında işbirliği anlaşması imzalamışlardır. Belgeye göre, Çin'de ilk defa Lanzhou Üniversitesi'nde Azerbaycan Araştırma Merkezinin kurulması planlanmaktadir (Real Press, 2018).

Azerbaycan ile Çin Arasında OBOR Çerçevesinde Imzalanan Belgeler: Azerbaycan Enerji Bakanı Parviz Shahbazov, Çin'deki OBOR Enerji Bakanlar Konferansı'na katılmış ve OBOR Ortaklığı Deklarasyonu'na imza atmıştır. Böylelikle OBOR çerçevesinde enerji ortaklığı sağlanması adına ilk adım atılmıştır. 2015'te, Hazar uluslararası taşımacılık rotasının koordinasyon komitesi Bakü'de bir araya gelmiş ve Çin-Kazakistan-Azerbaycan-Gürcistan-Türkiye rotasındaki konteyner hizmetini yoğunlaştırmak üzere bir anlaşmaya varılmıştır. Azerbaycan makamları, 2020 yılına kadar yaklaşık 400.000 konteynerin bu yolla taşınabileceğini ve katılımcilarına milyarlarca kar getireceğini ifade etmişlerdir (Valiyev, 2015, s. 1-4).

Aralık 2015'de Aliyev, Çin'e ziyarette bulunmuş ve iki ülke arasında ekonomik kuşağın yaratılması için mutabakat anlaşması imzalamıştır. 10 Aralık 
2015'te Azerbaycan Cumhuriyeti Eğitim Bakanlığı ile Çin Halk Cumhuriyeti Eğitim Bakanlığı arasındaki eğitim alanında işbirliği anlaşması ve "Azerbaycan Demiryolu" Kapalı Anonim Şirketi ile Çin Halk Cumhuriyeti Hükümeti arasındaki demiryolu işbirliği alanında işbirliği konusunda anlaşma imzalanmiştır (Beijing, 2019).

Alat Limanı: OBOR çerçevesinde yapımına başlanan büyük ekonomik projelerden birisi ise Bakü'deki uluslararası deniz ticaret limanı gelişmesi ile doğrudan bağlantılı Alat Liman'ının geliştirilmesidir.

Ayrıca Azerbaycan, gemi yapım endüstrisinin gelişiminde yeni bir aşamaya girmektedir. Denizcilik endüstrisi, ülkenin taşımacılık sektörünün kilit faktörlerinden birisini oluşturduğundan dolayı OBOR projesi ile beraber Azerbaycan deniz taşımacılığında ciddi reformlar yapmaktadır (Day.AZ, 2016).

Azerbaycan'ın, Çin devletinin Avrupa ile olan 600 milyar dolar civarındaki ticaret hacminden istifade etmesi için Orta Koridor'un aktif olarak kullanılması gerekmektedir. Bunun dışında, OBOR projesi vesilesiyle Hazar bölgesinin en stratejik coğrafyasına sahip olan Azerbaycan limanlarına lojistik alanlar ve serbest ticaret bölgelerinin kurulması, hem Çin ile Azerbaycan hem de Azerbaycan ile Batılı ülkeler arasında karşılıklı kazanmaya dayalı bir işbirliği geliştirecektir (Önem, 2018).

Azerbaycan, zengin petrol kaynakları ile tanınmakta bir nevi Hollanda Hastalığına yakalanmaktadır. Ancak son yıllarda Azerbaycan hükümeti ekonomik reformları sürekli olarak derinleştirerek petrol dışı ve gaz dışı alanlarda ekonomik kalkınmayı hızlandırmanın yanı sıra ülkenin yatırım ortamını iyileştirmeye çalışmaktadır. OBOR projesi, Azerbaycan'ı bu hastalıktan kurtaracak şu anki en uyumlu anahtarlardan biridir (Harward, 2016).

Tablo-1. Azerbaycan-Çin Ticaret Hacmi (2000-2018/Dolar/my:milyon-mr: milyar)

\begin{tabular}{llllcccc}
\hline Yillar & $\mathbf{2 0 0 0}$ & $\mathbf{2 0 0 4}$ & $\mathbf{2 0 0 8}$ & $\mathbf{2 0 1 2}$ & $\mathbf{2 0 1 4}$ & $\mathbf{2 0 1 6}$ & $\mathbf{2 0 1 8}$ \\
\hline İthalat & 23.090 & 145.485 & 478.834 & 631.856 & 697.082 & 703.805 & $1.196 \mathrm{mr}$ \\
\hline Ihracat & 4.878 & 31.718 & 498.968 & 183.768 & 63.862 & 382.027 & 113.573 \\
\hline
\end{tabular}

(Azerbaycan İstatistik Ajans1, t.y)

Azerbaycan İstatistik Ajansı'ndan alınan resmi verilere bakıldığında, Azerbaycan aleyhine derin bir dezavantajlı durumun olduğu, Azerbaycan'ın yıllar itibariyle Çin'e sattığı miktarın ciddi azalmalar gösterdiği, buna rağmen 
Çin'den yapılan ithalatın sürekli olarak yükseldiği görülmektedir. Çin bankalarının kredi verme noktasındaki rahatlı̆̆ ve ticaret hacminin Çin lehine gelişmesi Azerbaycan'ın Çin devletine finansman bağımlılığı yaşayabileceği endişesini doğurmaktadır. Çin devletinin Konfüçyüs Enstitüleri ile Azerbaycan'da üniversiteler ve kültür merkezleri açması, Çin dilini ve kültürünü Azerbaycan'da yaymaya çalışması, Azerbaycan gençlerine burs vererek onları Çin'e eğitim alamaya göndermesi de yumuşak güç ile Çin'in Azerbaycan'da etkili olmaya çalıştı̆̆ını, ekonomik ilişkilerin yanı sıra politik ve toplumsal boyutta da ilişkilerin geliştiğini göstermektedir.

\section{Kazakistan Cumhuriyeti}

Xi Jinping OBOR projesini 2013 yılında ziyaret ettiği Kazakistan'da ilan etmiştir. Çin açısından büyük önemi olan projenin ilanı için Kazakistan'ın seçilmesi tesadüf değildir (Aydın, 2018, s.74). Kazakistan Çin'in Orta Asya'daki en büyük ekonomi ve ticaret ortağıdır. Kazakistan ve Çin sadece ikili ilişkilerini bir sözleşme temeline dayandırmamakta aynı zamanda daha iyi işbirliği için güvenilir, ekonomik, siyasi ve stratejik çalışma alanı yaratmaktadırlar. Diğer OBOR ülkeleriyle kıyaslandığında Kazakistan, Aktav'daki Hazar bölgesinin Batı kıyıları ve Khorgos'daki Çin'le ortak sınıra sahip olması nedeniyle Çin'in Avrupa'ya ana kapısı olarak konumlanmıştır (Imomnazar, 2018, s.33).

Çin enerji kaynaklarına ihtiyaç duymaktadır ve buna paralel olarak Kazakistan enerjisinin bir numaralı ithalatçısıdır. Kazakistan'ın maden, petrol, gaz, inşaat, kimya, hafif sanayi ve ulaşım gibi Kazak imalat sanayisindeki öncelikli sektörlere odaklanan Çinli şirketler ile 20 'den fazla ortak proje yürütülmektedir. Mart 2015'te iki ülke nükleer enerji, tarım, demiryolu gibi değişik sektörlerde 23,6 milyar dolar değerinde işbirliği anlaşması imzalamıştır. Kazakistan'ın Aktöbe bölgesindeki Petrol ve Doğal Gaz Geliştirme Projesi, Kazakistan'ın Hazar kıyılarından Çin'in Sincan bölgesine doğru ilerleyen ve Çin'e doğrudan petrol ihraç etmek için planlanan bir projedir. Projedeki ana katılımcılar; Kazak petrol şirketi Kazmunaygas ve Çin Ulusal Petrol Şirketi CNPC'dir. Kazakistan doğal kaynaklarına bağlı kalmak yerine gelir kaynaklarını çeşitlendirerek büyümek için alternatifler üretmektedir. Kazakistan, OBOR girişimi ile Çin yatırımlarını ve teknolojilerini çekme ve Avrasya'daki en geniş transit merkezlerinden biri olma imkânına sahip olmaktadır (Peery, 
2018, s. 138). OBOR kapsamında faaliyete giren Çin-Kazakistan Lojistik Merkezi 2018 yılında Şubat ayından Haziran'a kadar yaklaşık 13.500 ton Kazakistan buğdayını işlemden geçirmiştir (Reynolds, 2018). Son zamanlarda Kazakistan'daki Khorgos Kara Limanından geçen nakliye hacminin artırılması, Çin'in OBOR girişiminin meyvelerini vermeye başladığını göstermektedir (Idan, 2018).

\section{Tablo 2. OBOR Kapsamında Kazakistan'da Yapılması Planlanan Ana Projeler}

\begin{tabular}{lcc}
\hline Yapılması Planlanan Projeler & Maliyet (Million Dolar \$) & Tarih \\
\hline Khorgos Terminali & 239 & $2014-2020$ \\
\hline Kuryk Limanı & 280 & $2015-2018$ \\
\hline Zhezkazgan-Beineu Demiryolu & 1.203 & $2012-2017$ \\
\hline Arkalyk-Shubarkol Demiryolu & 260 & $2012-2017$ \\
\hline Almatı-Shu demiryolu & 110 & $2015-2017$ \\
\hline Astana Yeni Demiryolu Aktarma Merk & 603 & $2013-2017$ \\
\hline Çimkent Lojistik Terminali & 46 & $2014-2017$ \\
\hline Astana Lojistik Terminali & 88 & $2014-2016$ \\
\hline Aktav Limanını Yenilenmesi & 121 & $2014-2017$ \\
\hline
\end{tabular}

Kaynak: Samruk ve Kazyna, 2018; Belt ve Road Updates 2018

Avrasya Kara Köprüsü: Yeni Avrasya Kıtasal Kara Köprüsü ve İkinci Kara Köprü olarak adlandırılır. Demiryolu koridoru Çin Lianyungang limanından çıkmaktadır. Polonya, Almanya ve Rusya'ya ulaşmadan önce Kazakistan ve Moğolistan'dan geçmesi planlanmaktadır. Yani Çin-LianyungangKazakistan-Moğolistan-Rusya-Polonya-Almanya hattını takip etmektedir. Bu rotayla ilgili bazı haritalarda Moğolistan bypass edilmekte ve doğrudan Kazakistan'dan geçmektedir.

Korghous-Aktav Demir Yolu: Çin ve Hazar arasında yeni demiryolu hattı olarak da bilinmektedir. 2015 yılında Astana yönetimi Çin'le ortak hareket ederek Hazar'ın petrol limanı şehri Aktav'dan Khorghous lojistik aktarma merkezine ulaşan ek bir trans-Kazakistan demiryolu inşa etmek için planları olduğunu ilan etmişlerdir (Cooley, 2016, s. 5).

Kazakistan'ın 2014 yılında önerilen ve 9 milyar değerindeki yeni ekonomi politikası Nurlu Yol Kalkınma Programı́nın OBOR ile amaç birlikteliği bulunmaktadır. Ancak Nurlu Yol politikası ulusal düzeydedir (Vakulchuk ve Overland, 2019, s. 119-120). Nurlu Yol politikasının otoyolları, demiryolları, limanları, eğitim ve kamu hizmetlerini, alt yapıyı modernleştirme ve geliştirme, Hazar bölgesindeki Aktav limanının modernleşmesi gibi hedefleri bulunmaktadır (Inan ve Yayloyan, 2019, s. 59). Çin'in Almatı Başkonsolosu Liao 
Hongbo (2019) OBOR'un ve Kazakistan'ın Nurlu Yol politikasının iki ülke arasındaki sanayi işbirliğini arttırdığını belirtmiştir. Rafis Abazov (2017, s. 170), Kazakistan resmi gazetesi Kazakhstanskaya Prauda, 2016 yılı içerisindeki bir yayınında, gelecek birkaç yıl içerisinde Çin'le 7,4 milyar dolar değerinde 11 projeyi uygulama planları olduğunu belirtmiştir.

Ana Çin bankaları (Bank of China, Industrial and Commercial Bank of China) Kazakistan'da faaliyet göstermektedir. Çin şirketleri Kazakistan'ın doğal maddeleri işleme endüstrisine yatırım yapmaktadır. Çin Ulusal Petrol Şirketi (CNPC) 12 milyar dolardan daha fazla petrol ürünlerine yatırım yapmış ayrıca enerji kaynaklarının Orta Asya'dan Çin'e arzını kolaylaştırmak için Kazakistan'da doğal gaz ve petrol boru hatları inşa etmek için 6,2 milyar dolar tedarik etmiştir (Vakulchuk ve Overland, 2019, s. 119).

Kazakistan Başbakan Yardımcısı Zhenis Kassymbek Orta Asya bölgesine yapılan doğrudan yabancı yatırımların \%75'nin Kazakistan'a ait olduğunu belirtmiştir. OBOR gibi büyük uluslararası projelerde aktif rol alan Kazakistan için bu rakam anormal değildir. Örneğin, OBOR'un parçası olarak yaklaşık 28 milyar dolar değerinde mevcut 55 endüstriyel proje Kazakistan ve Çinli şirketler tarafından yürütülmektedir (ASTANATIMES, 2019).

Khorgos Dry Port Kazakistan'ın Çin sinırında yer almakta ve 2015 Ağustos'tan beri faaliyet göstermektedir. Khorgos uluslararası bir kara limanıdır ve aynı zamanda sınır işbirliği merkezidir. 2015 yılında Kazak sınırında inşa edilen liman Kazakistan'ı Çin'in Lianyungang Limanı'na bağlamaktadır. Amacı sınır ötesi ticaret artırmak ve 2020'ye kadar 500.000 taşıma konteynırlı bir kapasiteye ulaşmaktır. Böylece dünyanın en geniş kara limanı haline gelecektir. Bu merkez aynı zamanda 'Yeni Dubai' olarak adlandırılmaktadır. Gümrüksüz ticarete imkân tanıyan merkez ayrıca bir endüstri lojistik merkezine sahiptir (Vakulchuk ve Overland, 2019, s. 121).

Yumuşak güç bakımından Çin diğer bölge ülkelerine göre Kazakistan'da daha görünür bir rol oynamaktadır. Dört Konfüçyüs Enstitüsü ülkede faaliyet göstermektedir ve Çin yerli kurumlarla işbirliği içindedir. 2008' den itibaren Çin dışarıda öğrenime devam etmek isteyen Kazak öğrenciler için çekici bir istikamet haline gelmiştir. 2016 yılında Çin Burs Konseyi (Çin'deki yabancı öğrencileri destekleyen devlet kurumu) Kazak öğrencilerin sayısının yaklaşık dört kat arttığını ve 12.000 'e ulaştı̆̆ını rapor etmiştir. Bu durum Çin'in artan popülaritesini göstermektedir (Vakulchuk ve Overland, 2019, s. 121-122). 
Son güncel proje ise Janatas Rüzgâr Enerjisi Santrali'dir. Kazakistan'ın elektrik ihtiyacını giderecek olan ve kapasitesi ile Orta Asya'daki en büyük rüzgâr enerjisi olacak Janatas 100 MW Rüzgâr Enerjisi Santrali'nin inşası 15 Temmuz 2019'da düzenlenen törenle başlamıştır. İki ülke arasındaki işbirliğinin önemli projelerinden biri olarak görülmektedir. Bu santralle Kazakistan'ın güneyindeki elektrik kesintilerinin azaltılması ve 300 kişiye istihdam yaratılması hedeflenmektedir. Santralin inşasını Chinapower ve Kazak Visor şirketi üstlenmektedir (CRİ, 2019).

Tablo 3. Kazakistan-Çin Ticaret Hacmi (2014-2019/Milyar/mr Dolar)

\begin{tabular}{lllllll}
\hline Yillar & $\mathbf{2 0 1 4}$ & $\mathbf{2 0 1 5}$ & $\mathbf{2 0 1 6}$ & $\mathbf{2 0 1 7}$ & $\mathbf{2 0 1 8}$ & $\mathbf{2 0 1 9}$ \\
\hline İthalat & $7.357 \mathrm{mr}$ & $5.087 \mathrm{mr}$ & $3.665 \mathrm{mr}$ & $4.694 \mathrm{mr}$ & $5.384 \mathrm{mr}$ & $6.570 \mathrm{mr}$ \\
\hline İhracat & $9.779 \mathrm{mr}$ & $5.480 \mathrm{mr}$ & $4.214 \mathrm{mr}$ & $5.797 \mathrm{mr}$ & $6.307 \mathrm{mr}$ & $7.820 \mathrm{mr}$ \\
\hline
\end{tabular}

(World Bank, t.y)

Kazakistan ile Çin arasındaki ticaret dengesi Azerbaycan ve Türkiye'ye göre şimdilik Kazakistan'ın lehinedir. Covid19 süreci Kazakistan'ın Çin ile olan ticaretini 2020 yılında etkileyecek gibidir. Ancak burada açıklanması gereken konu, Kazakistan'ın OBOR projesi vesilesiyle Çin devletine olan borcunun yıllar itibariyle artmasıdır. 1991'den günümüze Kazakistan'a 19 milyar dolar yatırım yapan Çin, Kazakistan'ı OBOR projesinin dünyaya açılan kapısı görmektedir. Çin, Kazakistan'da OBOR projesi kapsamında paylaşılan ortak hedeflerle ilgilenen güvenilir bir ekonomik ortak olarak görülmek istiyor. Özellikle Kazak gençleri için birçok eğitim, profesyonel atölye çalışması, kurs ve burs imkânı sağlayan Çin, Kazakistan'da Çin kültürünü ve dilini geliştirmek için 2019 itibariyle beş Konfüçyüs Enstitüsü işletmektedir. Çin'de okuyan Kazak vatandaşların sayısı şu anda 18.000 dolaylarına yaklaşmıştır. OBOR projesi ile yumuşak gücünü Kazakistan'a kanalize etmeye çalışan Çin, yüksek bütçeli OBOR projelerine sağladığı kredi imkânlarıyla da Kazakistan'ı finansman yönünden kendine bağımlı hale getirmektedir. Zira Kazakistan'ın Çin devletine OBOR projesi ile oluşan toplam borcu 12.3 milyar dolardır. Kazakistan'da OBOR projesinin çoğunlukla Çin şirketlerine ve bankalara fayda sağlayarak Çin mallarını dünya pazarlarına pompaladığı algısının değiştirilmesi gerekmektedir (Najibullah, 2019). Bunun da en iyi yolu gelirin toplum içindeki dağılımının adaletli yapılmasıdır. 


\section{Türkiye Cumhuriyeti}

Türkiye, OBOR projesini Orta Koridor Girişimi adı altında Çok Taraflı Uluslararası Ulaştırma Politikası olarak tanıtmıştır. Türkiye Orta Koridor' un bir parçası olarak tanitılırken bu projenin demiryolu ve karayolu güzergâhlarının altı çizilmiştir. Orta Koridor sayesinde Avrupa ve Asya arasındaki ticaret yolu mevcut ticaret ağı olan Trans-Sibirya Demiryolu'na kıyasla 2.000 km daha kısa, daha verimli ve ekonomik bir alternatif sunmaktadır. Bu sayede güzergâhın bir parçası olan Türkiye'nin konumunun da önemi artmaktadır. Türkiye, Kuşak ve Yol Girişimi adı altında yapılan ve 2015'te imzalanan "Türkiye Cumhuriyeti Hükümeti ile Çin Halk Cumhuriyeti Hükümeti Arasında İpek Yolu Ekonomik Kuşağı ve 21. Yüzyıl Deniz İpek Yolu ile Orta Koridor Girişiminin Uyumlaştırılmasına İlişkin Mutabakat Muhtırası"nın tarafı olmuştur (MFA, 2019).

\section{OBOR Projesi Kapsamında Türkiye İşbirliği ile Oluşturulan Çalışmalar}

OBOR projesinin temel ilkelerinden biri olan "kazan-kazan" ilkesine dayanarak, Çin' in bu projede ülkelerle kurduğu ilişkilerde bu ilkeyi gözeterek hareket etmesi beklenmektedir. Türkiye ile ilişkilerini proje kapsamında göz önünde bulundurduğumuzda karşılıklı olarak faydanın sağlanacağı bir stratejinin izlenmesi gerekmektedir. 2017 yılında Cumhurbaşkanı Erdoğan, Kuşak ve Yol Uluslararası İşbirliği Forumu'nda konu hakkında işbirliğini ve karşlıklı faydayı savunan projeyi destekleyici bir açıklama yapmıştır(BBC News Türkçe, 2017).

İki ülke arasında karşılıklı işbirliğinin desteklendiğinin örneklerinden biri 2005 yılında başlayan ve 2014 yılında tamamlanan Ankara - İstanbul hızlı tren hattıdır. Bu tren hattının en önemli özelliklerinden biri Çin'in ilk denizaşırı tren yolu projesi olmasıdır. Ankara-İstanbul tren hattının inşası için Çin 750 milyon dolarlık kredi finanse etmiştir. Bu tren hattı çalışması Çin Demiryolu İnşaat Şirketi, Çin Ulusal Makine İthalat-İhracat, Cengiz İnşaat ve IC İnşaat firmaları arasında ortak bir şekilde devam ettirilmiştir (Balcı, 2018, s. 7). Türkiye, OBOR projesine dahil olduktan sonra mevcut çalışmaların bir kısmını OBOR'a dahil etmişken aynı zamanda Orta Koridor güzergahından daha iyi faydalanabilmek için yeni projeler de entegre etmeyi planlamaktadır. OBOR'un temelinde yer alan hızl, ekonomik ve daha kısa yolların kullanılması, altyapı ve ulaşım yollarının güçlendirilmesi amacının yansıtıldığı bu 
çalışmalar alternatif yollara kıyasla daha tasarruflu ve verimli sonuçlar vermektedir. Güzergâhın, Türkiye ortaklığı ile gerçekleşen projeleri de yoğunlukla transit yolların geliştirilmesi üzerine olmuştur. Bu projelerden en önemlisi ve tamamlanmış olanı Bakü-Tiflis-Kars Demiryolu'dur.

Bakü-Tiflis-Kars Demiryolu (BTK): Bakü-Tiflis-Kars Demiryolu sırasıyla Azerbaycan, Gürcistan ve Türkiye'nin ortaklığıyla ortaya çıkmakta, Orta Koridorun en önemli bileşenlerinden birini oluşturmaktadır. 2008 yılında Türkiye'de temelleri atılan ve 2017'de tamamlanan demiryolunun toplam uzunluğu $838.6 \mathrm{~km}$ olarak planlanmıştır. Türkiye için maliyet 220 milyon dolar, toplam maliyeti ise 600 milyon dolar tutarındadır. 76 kilometresi Türkiye topraklarından geçen projenin 259 kilometresi Gürcistan'dan ve en uzun kısmı olan 503 kilometresi ise Azerbaycan'dan geçmektedir. BTK kapsamında Türkiye'de 4 istasyon, 3 köprü ve 76 km demiryolu inşa edilmiştir. Türkiye ile Gürcistan arasında sınır geçişi tünelle sağlanabilir hale getirilmiştir. Demiryolunun bitmesiyle hattın ilk aşamada yılda bir milyon insan ve 6.5 milyon ton yük taşıması öngörülürken, 2034 yılına kadar bu oranın üç katına çıkarak üç milyon yolcu ve 17 milyon tona ulaşması beklenmektedir (Akçay, 2017, s. 82).

Projenin amaçlarından biri olan Pekin'den Londra'ya veya Asya'dan Avrupa'ya kesintisiz demiryolu hattının önemli ayaklarından birini Türkiye oluşturmaktadır. BTK demiryolunun tamamlanmasıyla hat, Bakü'den sonra Türkmenistan, Türk Cumhuriyetleri ve Çin'e ulaşarak ve Ankara-İstanbul güzergâhı aracılığıyla Marmaray'la birleşmesinin ardından Bulgaristan, Sırbistan, Macaristan, Avusturya, Almanya, İsviçre, Fransa ve Manş Tüneli'yle Ingiltere'ye uzanmaktadır. Neticesinde demiryolu hattının bir ucunda Londra diğer ucunda Pekin bulunmaktadır (Üzümcü ve Akdeniz, 2014, s. 193). Türkiye topraklarında ise Edirne-İstanbul Demiryolu, Marmaray, İstanbul-Ankara YHT hattı (2012), Ankara-Kırıkkale-Yozgat-Sivas YHT, Sivas-Erzincan Hılı Tren ve Erzincan-Erzurum-Kars Hızlı Tren projeleri BTK ile birleştirilmesi planlanarak bu kesintisiz demiryolu projesinin en önemli halkalarını oluşturmaktadır (Akşam, 2018). Hazar Denizi geçişine sahip olan BTK projesi sayesinde Türkiye; Orta Asya, Uzak Doğu ve Güney Asya'ya demiryolu ulaşımını sağlayacak koridorun bir parçası olacaktır (Hajizadeh, 2015, s. 10). 
Marmaray: Marmaray, İstanbul'un Avrupa ve Asya yakasındaki demiryolu hatlarını, boğazın altından geçen bir tünel aracıllğıyla birleştiren bir demiryolu projesidir. Marmaray ve Yavuz Sultan Selim Köprüsü (3. Köprü), OBOR projesi kapsamında değerlendirilirken Pekin-Londra hattının orta çizgisini tamamlayan parçalar arasındadır. 2004 yılında çalışmalarına başlanan proje 2013 yılında tamamlanmıştır ve Marmaray aynı yıl hizmete açılmıştır. Marmaray Projesi, İstanbul'daki mevcut demiryolu sisteminin güçlendirilmesini sağlayarak, Avrupa yakasındaki Halkalı'yı Asya yakasındaki Gebze'ye kesintisiz bağlamaktadır (Marmaray, 2019). İstanbul'un iki yakasındaki demiryollarını bir tünelle birleştiren Marmaray projesi sayesinde yeni demiryolu hattı, $13 \mathrm{~km}$ 'si yeraltında olmak üzere toplam $76 \mathrm{~km}$ uzunluğa sahiptir (Belkaya, Özmen ve Karamut, 2008, s. 1). Orta Koridor güzergâhı özellikle demiryolu olarak Çin için önem arz etmektedir. BTK, Marmaray ve üçüncü köprü Demir İpekyolu olarak anılan bu güzergâhın orta kısmını oluşturmaktadır.

Yavuz Sultan Selim Köprüsü: İstanbul Boğazı'na yapılan üçüncü köprüdür. Sekiz şerit karayolu, iki şerit tren yolundan oluşan köprünün çalışmaları 2013 yılında başlayıp 2016 yılında hizmete açılmıştır. Köprüde bulunan iki adet raylı sistem yolu İzmit' ten Edirne'ye uzanırken, Marmaray ve metro yolları ile bağlantılı bir şekilde oluşturulmuştur (ICA, 2013). Yavuz Sultan Selim Köprüsü karayolu taşıma ve ulaşımında kolaylık sağlamanın yanı sıra demiryolu ulaşımında da Asya'dan Avrupa'ya uzanan güzergâhı çeşitlendirir niteliktedir. Bu sayede hem komşu şehirler hem de ülkeler arasında ticaret ve ulaşım yolları için yeni ve hızlı bir alternatif oluşmuştur (Karagöl, 2016). Marmaray, BTK, Avrasya Tüneli, Edirne Kars Tren hattı gibi projelerin uyarlandığı gibi Yavuz Sultan Selim Köprüsü de OBOR projesi kapsamındaki Orta Koridor'a göre uyarlanmıştır (Aybar, 2017).

Avrasya Tüneli: Avrasya Tüneli, yapımı 2011 yılında başlayan ve 2016 yılında hizmete açlan karayolu tüp geçit projesidir. Asya ve Avrupa kıtasını denizin altından geçen bir karayolu tüneli ile birbirine bağlamaktadır. Toplamda 14.6 kilometrelik uzunluğa sahip tünelin 5,4 kilometrelik bölümü, deniz tabanına inşa edilen iki katlı tünelden oluşmaktadır. Göztepe ve Kazlıçeşme noktalarını birleştiren bir güzergâh olan Avrasya Tüneli, Marmaray'dan sonra yapılan ikinci denizaltı projesi olmuştur. Öz kaynaklardan 320 milyon dolar ve yabancı kredilerden (Avrupa Yatırım Bankası, Avrupa İmar ve Kalkınma Bankası, Kore Eximbank, Sumitomo Mitsui 
Banking Corporation, Standard Chartered Bank, Mizuho Bank) 960 milyon dolarla finanse edilen Avrasya Tünelinin maliyeti yaklaşık 1 milyar 280 milyon dolardır (Avrasya Tüneli, 2020).

İstanbul Havaalanı: Yapımına 2015 yılından başlanan İstanbul Havaalanı 2019 yılında hizmete başlamıştır. Havaalanının ihalesini 26 milyar 140 Milyon Euro değerinde yapım bedeliyle beraber İstanbul Grant Airport (İGA) almıştır (Bianetorg, 2018). İstanbul havaalanı lojistik ve taşımacılık bakımından iki kıta arasında önemli bir noktadadır. Orta Koridor geçiş güzergâhında olması yeni lojistik açılımların sağlanmasına yardımcı olacaktır. BTK, Marmaray, Yavuz Sultan Selim Köprüsü, Avrasya Tüneli ve İstanbul Havaalanı yapımı tamamlanmış, Orta Koridor güzergahında bulunan ve OBOR projesiyle entegre olmuş çalışmalardır. Bu çalışmalar dışında yapım aşamasında olan veya planlanan ve OBOR ile entegresi söz konusu olan projeler mevcuttur.

1915 Çanakkale Köprüsü, 2023'te tamamlanması planlanan bir projedir. Bunun dişında önem arz eden bir diğer demiryolu projesi mevcuttur; EdirneKars Hızlı Tren Hattı ve Bağlantıları Projesi'dir. Bu proje için Çin ve Türkiye arasında 30 milyar dolarlık yatırımı kapsayan bir anlaşma yapılması beklenmektedir (Deutsche Welle, 2017). Bu projenin Kars'tan başlayarak 29 ilden geçip Marmaray üzerinden Edirne'ye bağlanması planlanmıştır. Bu konu hakkında Çinli yetkililer de Çin'in projeye desteğinin gerçekleşeceğini ifade etmiştir (Shanigai Daily, 2014). Türkiye Orta Koridor güzergâhına sadece kara ve demir yolları ile değil aynı zamanda limanları ile de katılmayı planlamaktadır. Filyos (Zonguldak), Çandarlı (İzmir) ve Mersin Limanları inşası bu amaç doğrultusunda planlanmaktadır (MFA, 2018).

Cumhurbaşkanı Erdoğan'ın Çin'deki yayın organında yayınlanan yazısında, OBOR projesi ile ilgili olarak; Türkiye'nin öncülük ettiği Orta Koridor girişiminden memnuniyeti ve katkılara devam edileceği belirtilmiştir. Yayınlanan yazıda; tamamlanmış olan BTK, Marmaray, Yavuz Sultan Selim Köprüsü, İstanbul Havaalanı, Avrasya Tüneli projelerinin ve planlanmakta olan projelerin OBOR kapsamında gerçekleşen altyapı çalışmaları olduğu, bunların yanı sıra Pekin ve Londra arasındaki güzergâhın sağlanması hedefi için gerekli tüm katkıların sunulacağı da belirtilmiştir (Bloomberg HT, 2019). Hâlihazırda birçok Çinli şirket de Türkiye pazarına giriş yapmıştır (DÜNYA, 
2018). Türkiye'nin Bir Kuşak Bir Yol projesinin bir parçası olacağı somutlaştırıldıktan sonra Çin yatırımlarının da ivme kazandığı gözlemlenmektedir (Bloomberg HT, 2018).

\section{OBOR Projesinin Çin ve Türkiye İlişkilerine Etkisi}

Çin' in 1971'de Birleşmiş Milletler Güvenlik Konseyi'ne girmesinin ardından iki ülkenin ilişkileri oldukça ilerlemiştir. Bu dönemden sonra iki ülke arasinda önemli siyasi aktörlerin ziyaretleri gerçekleşmiş ve Türkiye' de Çin pazarının önemi artmıştır. 2000'li yıllarla beraber artan ilişkiler 2010 yılında Stratejik Ortaklık seviyesine ulaşmıştır. Ekonomik ilişkilerin yanı sıra kültürel ilişkiler de geliştirilmeye çalışılmıştır ve bu çerçevede 2012-2013 yılları Çin ve Türkiye yılları olarak kutlanmıştır (Akçay, 2017, s. 76-77).

Tablo 4. Türkiye'nin Çin ile Dış Ticareti 2007-2019 (Milyar Dolar)

\begin{tabular}{llccl}
\hline Yil & İhracat & İthalat & Hacim & Denge \\
\hline $\mathbf{2 0 0 7}$ & 1.039 .523 & 13.234 .092 & 14.273 .615 & -12.194 .569 \\
\hline $\mathbf{2 0 0 8}$ & 1.437 .204 & 15.658 .210 & 17.095 .414 & -14.221 .007 \\
\hline $\mathbf{2 0 0 9}$ & 1.599 .139 & 12.676 .573 & 14.275 .712 & -11.077 .433 \\
\hline $\mathbf{2 0 1 0}$ & 2.269 .175 & 17.180 .806 & 19.449 .982 & -14.911 .631 \\
\hline $\mathbf{2 0 1 1}$ & 2.466 .316 & 21.693 .336 & 24.159 .652 & -19.227 .019 \\
\hline $\mathbf{2 0 1 2}$ & 2.833 .255 & 21.295 .242 & 24.128 .497 & -18.461 .987 \\
\hline $\mathbf{2 0 1 3}$ & 3.600 .865 & 24.685 .885 & 28.286 .751 & -21.085 .020 \\
\hline $\mathbf{2 0 1 4}$ & 2.861 .052 & 24.918 .224 & 27.779 .276 & -22.057 .171 \\
\hline $\mathbf{2 0 1 5}$ & 2.414 .790 & 24.873 .457 & 27.288 .247 & -22.458 .666 \\
\hline $\mathbf{2 0 1 6}$ & 2.328 .044 & 25.441 .433 & 27.769 .477 & -23.113 .389 \\
\hline $\mathbf{2 0 1 7}$ & 2.936 .262 & 23.370 .620 & 26.306 .882 & -20.434 .358 \\
\hline $\mathbf{2 0 1 8}$ & 2.912 .539 & 20.719 .063 & 23.631 .602 & -17.806 .524 \\
\hline $\mathbf{2 0 1 9}$ & 2.580 .000 & 18.490 .000 & 21.070 .000 & -15.910 .000 \\
\hline
\end{tabular}

Kaynak: (ticaret.gov, t.y)

Türkiye, Asya Pasifik Bölgesi'nde yer alan Çin devletinden en fazla ithalat yapan ülkedir. Ancak ihracat bakımından Türkiye daha gerilerde kalmıştır. Türkiye ve Çin arasındaki ticari ilişkilerde dış ticaret oranı 2005 yılında toplamda 7.4 milyar dolarken bu rakam 2010 'da 19.4 ve 2018'de 23.6 milyar dolara yükselmiştir. Türkiye'nin ihracatı ise 2018 yılında 2.9 milyar dolarken, ithalatı 20.7 milyar dolar civarında olmuştur. Türkiye'nin ihracatında Çin yüzde 1.7 pay sahibiyken, ithalatta yüzde 9.2 değerinde bir paya sahiptir (Dilek, Özdemir ve İstikbal, 2019, s. 29-30).

Bu bağlamda değerlendirdiğimizde Türkiye'nin Çin pazarına daha fazla dâhil olması gerekliliği ortaya çıkmaktadır. OBOR projesi, Türkiye ile Çin arasında daha kısa ve daha hızlı ticaret yolları oluşturması sebebiyle iki ülke 
arasındaki ticaret açı̆̆ının giderilmesi için uygun bir zemin sunmaktadır. Çin, OBOR projesini ve Orta Koridoru erişmekte zorlandığı Avrupa pazarı için kullanırken Türkiye benzer bir durum içinde olup uzak kaldığı Asya pazarına açılma fırsatı bulmuştur. Projenin bağlamında karşılıklı fayda göz önünde bulundurulduğu halde ülkeler arasındaki ticari ilişkilerin bu şekilde güçlenmesinin doğrudan bir sonuç olacağ1 görülmektedir.

Çin'in Türkiye'deki yatırımları genellikle enerji alanına yoğunlaşmıştır. Ancak OBOR projesinin hayata geçmesinin ardından bu yatırımlar, genelde altyapı ve taşımacılık alanına yoğunlaşmıştır. 2005-2018 yılları arasında Çin, Türkiye'de yaklaşık 15 milyar dolar yatırım gerçekleştirmiştir. Diğer birçok koridor ülkesinde olduğu gibi bu yatırımların büyük kısmı ulaşım, altyapı ve enerji üzerine yoğunlaşmıştır. Yatırımların yaklaşık 9 milyar doları enerji ve 2.3 milyar doları demiryolu alanında gerçekleşmiştir. OBOR görüşmelerinin yoğunlaşmaya başladığı 2013 yılına kadar olan 8 yıllık dönemde gerçekleşen yatırımlar toplam yatırımın \%44'ünü oluştururken, OBOR projesinin yoğunluk kazandığı süreçte ise yatırımlar yoğunlaşmış ve toplam yatırımın \%56'sı bu dönemde gerçekleşmiştir (Scissors, 2020).

OBOR projesinin açılanmasından bu yana beklendiği gibi Çin' in yatırımları artmaktadır. Özellikle Çin temelli ICBC ve Bank of China bankalarının Türkiye pazarına katılmasıyla beraber iki ülke arasındaki ekonomik ve ticari bağlar yoğunluk kazanmıştır. Bu sayede Türkiye'de ticaret yapmaya başlayan firmaların da sayısı artmaktadır. Bu bağlamda Çin-Türkiye ilişkilerinin OBOR projesi başladıktan sonra gelişme gösterdiğini söylemek mümkündür (Dilek, Özdemir ve İstikbal, 2019, s. 48).

\section{Borç Diplomasisi}

Bir Kuşak Bir Yol projesi hep barışçıl, öncelikle ekonomik ilişkilere ağırlık veren, Doğu ile Batı arasında herkesin istifade edebileceği ticaret yolları inşa edecek olan bir kazan-kazan projesi olarak ele alınmaktadır. Burada farklı bir noktaya dikkat etmek gereklidir. Bu nokta ise Çin devletinin ekonomik ilişkilerde farklı bir yaklaşıma sahip olduğu konusudur.

Çin devleti, finansmana ihtiyaç duyan özellikle üçüncü dünya ülkelerine düşük fazili krediler verirken, vermiş olduğu kredinin ilgili ülkeler tarafından nasıl ve hangi projeler için harcandığına dikkat etmemektedir. Batılı ülkeler ise Çin'in yaptığının aksine kredi verirken verdikleri kredinin nasıl ve 
hangi alanlarda harcanağına dair şeffaf olunmasını istemekte ve eğer gerekli görür iseler bunun için ilgili kurumların kurulması ve paranın takibinin yapılmasını istemektedirler. Finansmana ihtiyaç duyan gelişmekte olan devletler genellikle şeffaflık mekanizmalarına karşı çıktıklarından Çin gibi hiçbir şey sormadan kredi veren ülkelerin kapılarını çalmaktadırlar. Böylece Çin devleti Batılı ülkelere karşı finansman konusunda önemli bir alternatif haline gelmektedir. İşte tam olarak bu noktada Çin'den almış oldukları düşük faizli borçların nasıl harcanağına müdahil olunmaması daha fazla borçlanılmasına sebep olmakta ve borç alan ülkeleri adeta bir borç batağına sürüklemektedir. "Borç Diplomasisi" kavramı ise bu süreçte devreye girmektedir. Çen devleti, uyguladığı bu kasıtlı borçlandırma ile borcunu ödeyemeyen ilgili devletlerin önemli kamu varlıklarına belli süreler dahilinde el koymaktadır. Başka bir ifadeyle, Çin devleti, borcunu ödeyemeyen devletlere siyasi baskı uygulayarak borçlarına karşlık siyasi ve ekonomik pozisyonunu güçlendirmekte, borçlu olan ülkeleri kendine daha fazla bağımlı hale getirerek küresel tahakkümünü güçlendirmektedir (Yılmaz, 2019, s.15-16).

Sri Lanka'nın Hambantota limanının hakları China Merchant Grup'a 99 yıllığına kiralanmıştır. Pakistan'ın Gwadar kentindeki liman Çin'e 44 yıllığına devredilmiştir. Mombasa Limanı Çin'e verilmiştir. Myanmar'da Çin'in 1.5 milyar dolar yatırım ile inşa ettiği petrol boru hattının işletme yetkisi 7 milyar dolar ile Çin' e devredilmiştir (Fulton, 2016). Malezya'da Devlet Başkanı Mhathir Muhammed'in göreve gelmesi ile Çin ile olan ilişkiler değerlendirilmiş ve 20 milyar dolarlık demiryolu ile 2.3 milyar dolarlık doğalgaz boru hattı projeleri iptal edilmiştir. Malezya daha sonra bu projelere onay vermiştir (OBOReurope, 2019). Maldivler, Çin ile olan borç anlaşmaları ile projelerin tekrar gözden geçirilmesi gerektiğini dile getirmektedir (Mundy ve Hille, 2019).

Orta Asya devletlerinden Kırgızistan ve Tacikistan için de ekonomik olarak çeşitli handikaplar vardır. Özellikle Kırgızistan'ın toplam dış borcunun \%42'si Çin devletinedir. Tacikistan'ın ise toplam dış borcu 2.3 milyar dolar iken bunun 1.2 milyar doları Çin'e olan borcudur. Ayrıca 2018 Nisan ayında Çinli şirkete maliyeti yaklaşık 30 milyon olan Duşanbe hidroelektrik istasyonu karşılığında, Yukarı Kumarg altın maden ocağı devredilmiştir. Bu maden ocağ ile birlikte toplam 7 maden ocağ ve bir kömür maden ocağ 1 Çin'e devredilmiştir (Furukawa, 2018). 
Bunlar dışında proje kapsamında yapılmayan fakat kullanım hakları Çin'e devredilmiş olan Yunanistan'ın Pire Limanı ve Türkiye'deki Kumport Limanı bulunmaktadır. Çinli Cosco Denizcilik şirketi Kumport Limanı́nın 2015'te \% 65 hissesini 940 milyon dolara satın almıştır (Ekonomist, 2017). Pire Limanı'nı ise ekonomik sıkıntılar yaşayan Yunanistan tarafından 2016 y1lında, aynı Çinli şirket Cosco'ya \% 67'lik hissesi ile satılmıştır (Deutsche Welle, 2016). Çin, toplamda 8 ülkede 15 terminali işletme hakkını almıştır. Ayrıca Türkiye gibi birçok ülke Çin ile yapılacak bu projede ihracat ve ithalatta karşılıklı dengelerin sağlanamamasından hoşnut değillerdir (Deutsche Welle, 2017). Çin' in borç diplomasisi yolu ile borçlarına karşılık Türk devletlerinin ellerindeki önemli kurumlara ilerleyen zamanlarda el koyması muhtemel aksiyonlardandır. Adı geçen üç Türk devletinin Çin ile olan finansal ilişkilerinde yukarıda verilen örnekleri dikkate alması ve bu diplomasinin paydaşları olmamaları gerekmektedir.

\section{Sonuç}

Bir Kuşak Bir Yol projesinin kapsadığı alan dikkate alınırsa önem arz edilmesi gereken iki husus olduğu görülecektir. Birincisi, OBOR projesini salt altyapı/üstyapı yatırımları ve sağlanan büyük ölçekli krediler üzerinden ele almanın ve anlamlandırmanın yanlış olduğu hususudur. İkincisi ise bu projenin aynı zamanda Çin Halk Cumhuriyeti'nin dışa açılma girişiminin ve yeni bir düzen inşa etmeye yönelik dış politika vizyonunun en önemli enstrümanlarından biri olması hususudur. Azerbaycan, Kazakistan ve Türkiye devletleri ise Çin'in bu vizyonunun ayrılmaz parçalarıdır. Bundan dolayı Çin, borç diplomasisini kullanarak tıpkı Sri Lanka, Pakistan, Kenya, Tacikistan ve diğer birçok ülkede yaptı̆̆ gibi bu üç Türk devletinin önemli milli kurumlarına borçları karşıllı̆ında el koyabilir. Bu seçenek şu anda masada olmasa da gerek OBOR ile Çin'e olan borçlanmanın artması gerekse Çin ile olan ticaret hacminde Çin lehine gelişmeler yaşanmasından dolayı unutulmaması gereken bir seçenektir. Borç diplomasisi ile Çin birçok ülkeyi borçlandırması ve akabinde bu borçlanmayı politik bir baskı unsuru olarak kullanması OBOR projesinin salt ekonomik bir proje olmadığını göstermiştir.

Bir Kuşak Bir Yol projesi duyurulduktan bu yana hem büyük bir ilgi hem de endişeyle karşılanmıştır. Projenin duyurusunu yapan Çin'in dünyada gi- 
derek güçlenen bir devlet haline gelmesi, proje için endişelerin temelini oluşturmuştur. Bu endişeler, OBOR projesinin Çin' in bir yayılmacı politikası olduğu fikri üzerinde yoğunlaşmıştır. OBOR projesinin kapsamll, kıtalararası bir proje olması sebebiyle bu düşüncelerin dile getirilmesi olağandır. Devletlerin attığı birçok adım elbette kendileri için siyasi, ekonomik veya askeri stratejik faydaları gözetmektedir. Bu bağlamda projenin birer parçası olan Azerbaycan, Kazakistan ve Türkiye'nin de bu durumu dikkate alması gerekmektedir.

ABD'den sonra dünyanın en büyük ikinci ekonomisine sahip olan Çin'in Kazakistan'a olan coğrafi yakınlığı bölgede aktif rol oynamasında etkilidir. Kazakistan'ın 1991 yılında elde ettiği bağımsızlık sonrası Çin'in bu ülkeye olan ticareti ve bölgedeki yatırımları da hızlı bir şekilde artmıştır. OBOR ile Çin'in Kazakistan'daki yatırımları çalışmada da gösterildiği üzere yükselen bir ivme göstermektedir. Çin, OBOR sayesinde bir yandan gereksinim duyduğu doğal ve hammadde kaynaklarına erişmek için Kazakistan'ın altyapısını güçlendirmekte, diğer yandan ise Kazakistan' da ekonomik ve siyasi nüfuzunu arttıracak bir pazar oluşturmaktadır. Bir başka ifadeyle, Çin, dünyaya yönelik ekonomik ve sonrasında oluşabilecek politik kazanımları için Kazakistan'ı bir geçiş/çıkış ülkesi olarak görmektedir. Ancak Çin'in Kazakistan'da giderek artan yumuşak gücü ve Kazakistan'ın OBOR projesinden dolayı Çin'e 12 milyar dolar civarında borcu olması Kazakistan'ın dikkat etmesi gereken bir konudur. Azerbaycan ve Türkiye ise benzer bir senaryoya sahiptir. Her iki ülke de Çin devleti ile yaptıkları ticarette büyük bir ticaret dengesizliği içerisindedirler. İki devletlin de Çin'e olan ihracatları zamanla azalırken Çin'den yaptıkları ithalat ciddi boyutlarda yükselmektedir. Çin'in özellikle Kazakistan ve Azerbaycan'da Konfüçyüs Enstitüleri üzerinden yürüttüğü sosyal temelli politikalar, açtı̆̆ üniversiteler, araştırma merkezleri, Kazak ve Azerbaycan gençlerine burs verip onları Çin'e eğitim için göndermesi OBOR projesinin yukarıda bahsedilen toplumsal vizyonunun bir yansımasıdır. 


\section{EXTENDED ABSTRACT}

\section{The Effect of One Belt One Road Project on Azerbaijan, Kazakhstan, and Turkey \\ Serdar Yilmaz \\ Muğla Sıtkı Koçman University}

The One Belt One Road Project is a product of the efforts to reinforce the global domination of the People's Republic of China that is implementing huge economic, social, cultural and infrastructure projects in the 21st century. The OBOR project, announced by Chinese president Xi Jinping in 2013 in Nur-Sultan the capital city of Kazakhstan, aims to connect China and Europe with advanced roads, high-speed train lines, power lines, ports, pipelines, fiber optic lines and other infrastructure elements.

From the Chinese perspective, the OBOR project has five basic strategies. These are: to diversify its policy, to establish links between the energy sector, transportation, infrastructure, digital security, to remove trade and investment barriers, to integrate with financial markets and to gain international understanding. The most important connections countries of this strategy which lays from Asia to Europe are Azerbaijan, Kazakhstan and Turkey.

The study refers why Azerbaijan, Kazakhstan and Turkey play significant roles for OBOR project. It also refers which projects have been implemented in Turkish states for the OBOR initiative. Increasing financial dependency of Turkish states on China is another matter that the study deals with. There are two reasons why these three countries were chosen. First, these Turkish countries have the most amount of trade rates with China. Secondly, China has made the most amount of investment to these three states among the other Turkish states.

Considering the area covered by the OBOR project, it will be seen that there are two important issues. The first is that it is wrong to consider and interpret the OBOR project solely on the basis of large-scale loans and infrastructure investments. The second is that this project is also one of the most important instruments both for the People's Republic of China's initiative to open up to the world and its foreign policy vision for building a new economic order. 
However, there is an important economic issue to be considered here. The Chinese government does not interfere much in how and where the loan it lends under OBOR will be used. However, Western countries set transparency conditions when making financial aid and China even regards such conditions as an intervention in domestic politics. Especially since the developing and third world countries share the same opinion with China, the Chinese state is seen as an important money and alternative resource against the Western countries. The lack of rigid intervention in how to spend the high amount of incoming loans drags the states that borrowed from China into debt trap. At this point, the "debt diplomacy" implemented by the Chinese state begins. With its deliberate lending and debt diplomacy, China seizes the important assets of states that can not pay their loans in Africa and Asia. In other words, bilateral relations that started with economic motives turn into a political pressure tool with debt diplomacy. With this strategy, the Chinese state consolidates its global domination by increasing the number of economically dependent states.

Therefore, by using debt diplomacy, China can seize the important national institutions of Azerbaijan, Kazakhstan and Turkey in exchange for their debts, just as it did in Sri Lanka, Pakistan, Kenya, Tajikistan and many other countries. Although this option is not on the table at the moment, but it is an option that should not be forgotten due to the increase in borrowing money from China via OBOR project and the negative developments against the Turkish states in the trade volume with China.

China's attitude of creating may economicially dependant countries via dept diplomacy and using this borrowing as an instrument of political pressure has demonstrated that the OBOR project is not just an economic project.

The geographical proximity of China to Kazakhstan is effective in its active role in the region. After the independence of Kazakhstan in 1991, China's trade in this country and investments in the region increased rapidly. With OBOR project, Chinese investments in Kazakhstan show a rising momentum as shown in the study. On the one hand, thanks to OBOR, China strengthens the infrastructure of Kazakhstan in order to access the natural and raw material resources it needs. On the other hand, China creates a market that will increase its economic and political influence in Kazakhstan. In other words, China sees Kazakhstan as a transit/exit country for its economic and political gains. Kazakhstan is the first point where the economic silk road started to 
reach the world. However, the increasing soft power of China in Kazakhstan and the fact that Kazakhstan owes China around 12 billion dollars due to the OBOR project is an issue that Kazakhstan should pay attention to. Otherwise, Kazakhstan may face the experience of many countries transferring their important assets to the Chinese state.

Azerbaijan and Turkey have a similar scenario. Both countries are in a great trade imbalance in their trade with the Chinese state. While the exports of both states to China decrease over time, their imports increase significantly. Azerbaijan is relatively freer in its relations with China because both it has little trade and does not have any debt to China. However, Turkey has a remarkable disadvantage in trade as Turkey's debt to the Chinese state is rising gradually over the years. This may mean that China may be likely to implement dept diplomacy in Turkey to seize important Turkish assets. It is necessary to evaluate the sale of Yavuz Sultan Selim Bridge (connects Asia and Europe) to China in this direction.

Although the increase in mutual dependency is beneficial for all parties, it is clear that the Turkish states are more dependent on the one-to-one trade with China which is itself an export champion. At this point, these three countries in need of foreign investments have an important place in Chinese foreign policy, both because they are the gateways to Europe and they are not in a position to pose any threat to China. Last but not least, it is also useful to mention the soft power elements used by the OBOR project. Opening of the soft power instrument of Confucius Institutes, univers, ties, research centers and scholarship opportunities for the Turkish youth to study in China increase soft power elements of China through OBOR project.

\section{Kaynakça / References}

Abazov, R. (2017). One belt one road strategy: The views from Kazakhstan. Caucasus International, 4(2),

Akçay, N. (2017). Turkey-China Relations within the concept of the new silk road project. Bölgesel Araştırma Dergisi-ANKASAM, 1(3).

Avrasya Tüneli, dünyada deniz altından geçen ilk iki katl karayolu tünelidir, Avrasya Tüneli, 10.12.2020, (11.12.2020) tarihinde https://www.avrasyatuneli.com/kurumsal/nasil/finansman adresinden erişilmiştir. 
Aybar, S. (2017). Tek kuşak tek yol insiyatifi bağlamında Türkiye - Çin ilişkileri, TASAM. 20.06.2020 tarihinde https:/tasam.org/tr-TR/Icerik/45102/tek kusak tek yol insiyatifi baglaminda turkiye - cin iliskileri adresinden erişilmiştir.

Aydın, F. (2018). Kuşak ve yol projesinin ekonomi politiği ve Türkistan. Gazi Üniversitesi Sosyal Bilimler Enstitüsü, Yayımlanmamış Yüksek Lisans Tezi, Ankara.

Baghirov, O. (2019). Azerbaijan and China Sign $\$ 800$ million economic package: The geo-economic mplications. Eurasia Daily Monitor 16(78).

Balcı, Z. (2018). Çin'in “Ípek Yolu” projesi. INNSAMER, 27.06.2020 tarihinde https://insamer.com/tr/cinin-yeni-ipek-yolu-projesi 1111.html adresinden erişilmiştir.

Belkaya, H., Özmen, H. İ. ve Karamut, İ. (2008). The Marmaray Project: Managing a large scale project with various stake holders, Proceedings of the World Congress on Engineering. (28.07.2020) tarihinde http://www.ancientportsantiques.com/wp-content/uploads/Documents/ETUDESarchivees/BlackSeaInfill/Marmaray-Belkaya2008.pdf adresinden erişilmiştir.

Cooley, A. (2016). The emerging political economy of Obor. Center For Strategic \&International Studies, Washington, USA.

Çində ilk dəfə Azərbaycan Araşdırmalar Mərkəzi yaradılacaq. (25.05.2018). Real Press.

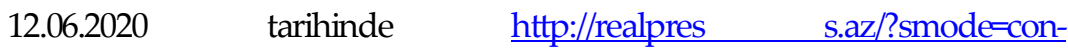
tent\&item=Cinde ilk defe Azerbaycan Arashdirmalar Merkezi yaradilacaq-2018-09-25+11\%3A49\%3A50 adresinden erişilmiştir.

Çinli bin şirketin yolu Türkiye'ye düştü. (Haziran 29, 2018). Dünya Gazetesi, 21.07.2020 tarihinde https://www.dunya.com/ekonomi/cinli-bin-sirketin-yolu-turkiyeye-dustu-haberi-420779 adresinden erişilmiştir.

Day.AZ. (2016). Çin yeni strategiya izindo - 'Bir Qurşaq, Bir Yol, 02.07.2020 tarihinde https://news.day.az/pgbrands/755182.html adresinden erişilmiştir.

Modern İpek Yolu projesi: Beklentiler ve kuşkular. (2017). Deutsche Welle Türkçe, (25.06.2020) tarihinde https://p.dw.com/p/2cwE7 adresinden erişilmiştir.

Dilek, Ş. (2017). Demirden İpek Yolu: Bakü-Tiflis-Kars demiryolu hatt. Setav, (14.05.2020) tarihinde https://www.setav.org/demirden-ipek-yolu-baku-tifliskars-demiryolu-hatti/ adresinden erişilmiştir.

Dilek, Ş., Özdemir, Z. B. ve İstikbal, D. (2019). Asya yüzyllnda Türkiye - Çin ekonomik ilişkileri. SETA: Ankara.

Erdoğan: Modern İpek Yolu vatandaşlarımızın hayat standardını artıracak. (14 Mayıs 2017). BBC News Türkçe, (28.07.2020) tarihinde https://www.bbc.com/turkce/haberler-dunya-39913491 adresinden erişilmiştir. 
Erdoğan: Yeni bir dünya sisteminin kurulmasında Türkiye ve Çin'e büyük görevler düşüyor. (Temmuz 1, 2019). Bloomberg HT, (02.07.2020) tarihinde https://www.bloomberght.com/erdogan-yeni-bir-dunya-sisteminin-kurulmasinda-turkiye-ve-cine-buyuk-gorevler-dusuyor-2227599 adresinden erişilmiştir.

Features of the 3rd İstanbul Airport. (2018) Bianetorg, 01.07.2020 tarihinde https://bianet.org/english/other/202130-impressum-of-the-3rd-istanbul-airport adresinden erişilmiştir.

Furukawa, E. (2018). Belt and road debt trap spreads to Central Asia. Nikkei Asian Review, $\quad 14.06 .2020$ tarihinde https://asia.nikkei.com/Spotlight/Belt-andRoad/Belt-and-Road-debt-trap-spreads-to-Central-Asia adresinden erişilmiştir.

Hajizadeh, M. E. (2015). Great silk road and the "Baku-Tbilisi-Kars" project. Reseachgate, (25.06.2020) tarihinde $\quad$ https://www.researchgate.net/publication/318589145 BAKU-TBILISI-KARS PROJECT adresinden erişilmiş̧tir.

Hongbo, L. (2019). Çin, Kazakistan için rüzgâr eneriisi santrali inşa ediyor, 17.07.2020 tarihinde http://turkish.cri.cn/1781/2019/07/16/1s199013.htm adresinden erişilmiştir.

Idan, A. (2018). China's belt and road mitiative: Relieving landlocked Central Asia. Analytical Articles, (12.07.2020) tarihinde adresinden erişilmiştir. https://www.cacianalyst.org/publications/analytical-articles/item/13510-chinas-belt-and-road-initiative-relieving-landlocked-central-asia.html adresinden erişilmiştir.

Imomnazar, I. (2018). Impact of «one belt, one road» initiatives to the economy of Central Asian countries. International Journal of Business and Economic Development, 6(2). 29-36.

Inan, F. ve Yayloyan, D. (2019). New economic corridors in the South Caucasus and the Chinese one belt one road. Ankara:TEPAV,

Karagöl, T. E. (2016). İpek Yolu'nun bağlantss: 3. Köprü. SETA, (01.07.2020) tarihinde https://www.setav.org/ipek-yolunun-baglantisi-3-kopru/ adresinden erişilmiştir.

Kısayoldan Kazandık. (24.03.2019), Milliyet (14.06.2020) tarihinde http://www.milliyet.com.tr/kisayoldan-kazandik--ekonomi-2847353/adresinden erişilmiştir.

Kumport Limanina 100 milyon yatırlacak. (Ekim 18, 2017). Ekonomist. (09.07.2020) tarihinde https://www.ekonomist.com.tr/haberler/kumport-limanina-100-milyon-yatiracak.html adresinden erişilmiştir. 
Malaysia in the BRI again, One Belt One Road Europe, OBOReurope, 20/04/2019, (27.06.2020) tarihinde https://www.oboreurope.com/en/malaysia-bri-again/ adresinden erişilmiştir.

Modern İpek Yolu nereye çkar?, (Ekim 18, 2017). Bloomberg HT, (21.06.2020) tarihinde https://businessht.bloomberght.com/piyasalar/haber/1495794-modern-ipekyolu-nereye-cikar adresinden erişilmiştir.

Modern İpek Yolu projesi: Beklentiler ve kuşkular, (14.05.2017). Deutsche Welle, (12.07.2020) tarihine https://www.dw.com/tr/modern-ipek-yolu-projesi-beklentiler-ve-ku\%C5\%9Fkular/a-38832963 adresinden erişilmiştir.

Mundy, S. ve Hille, K. (2019). The Maldives counts the cost of its debts to China. Financial Times, (27.07.2020) tarihinde https://www.ft.com/content/c8da1c8a-2a1911e9-88a4-c32129756dd8 adresinden erişilmiştir.

Najibullah, F. (September 10, 2019). Anti-Chinese protests don't deter Kazakh President from visiting Beijing. RFERL. (01.07.2020) tarihinde https://www.rferl.org/a/anti-chinese-protests-don-t-deter-kazakh-presidentfrom-visiting-beijing/30157466.html\#: :text=According\%20to\%20official\%20statistics $\% 2 \mathrm{C} \% 20$ Kazakhstan's,2018\%20was\%20about $\% 20 \% 2412.3 \% 20$ billion adresinden erişilmiştir.

Önem, A. E. (2018). Yeni İpek Yolu yeni gelecek. (07.07.2020) tarihinde http://eminonen.com/2018/08/10/turkiyeye-yatirim-sadece-turkiyeye-degil-ortadogu-avrasya-ve-kusak-ve-yol-projesi-ile-ortak-gelecegimize-yatirimdir/ adresinden erişilmiştir.

Peery, B. (2018). China vs. U.S.: A political analysis of U.S.-China competition, a police state vs. a Democracy. Archway, USA.

Pire Limanı Satldı, (08.04.2016). Deutsche Welle, (30.06.2020) tarihinde https://www.dw.com/tr/pire-liman\%C4\%B1-\%C3\%A7inlileresat $\% C 4 \% B 11 d \% C 4 \% B 1 / a-19173959$ adresinden erişilmiştir.

Poghosyan, B. (2018). China's OBOR initiative: Opportunities for the South Caucasus. Emerging Europe, (30.05.2020) tarihinde https://emerging-urope.com/voices/chinas-obor-initiative-opportunities-for-the-south-caucasus/ adresinden erişilmiştir.

Prezidentin Davosda keçirilən Dünya İqtisadi Forumunda görüşləri xüsusi əhəmiyyət kəsb edir, (25.01.2019). BIZIMYOL, (24.07.2020) tarihinde https://www.bizimyol.info/az/news/137848.html adresinden erişilmiştir.

Reynolds, S. (2018). Central Asia Sees opportunities in Us-China trade war. eurasia.net, (17.07.2020) tarihinde https://eurasianet.org/central-asia-sees-opportunity-inus-china-trade-war adresinden erişilmiştir. 
Scissors, D. (2020). China's Global Investment in 2019: Going Out Goes Small, 22.12.2020 tarihinde https://www.aei.org/wp-content/uploads/2020/01/Chinas-global-investment-in-2019-1.pdf adresinden erişilmiştir.

Tuz Gölü Doğalgaz Depolama Projesi Finansman İmza Töreni. (t.y). T.C. Enerji ve Tabii Kaynaklar Bakanlı̆̆ı, (29.06.2020) tarihinde https://www.enerji.gov.tr/tr-TR/Bakanlik-Haberleri/Tuz-Golu-Dogalgaz-Depolama-Projesi-Finansman-ImzaToreni adresinden erişilmiştir.

THE ASTANA TIMES. (2019). Kazakhstan can become one of global leaders in investment attractiveness, 10.07.2020 tarihinde https://astanatimes.com/2019/07/kazakhstan-can-become-one-of-global-leaders-in-investment-attractiveness/ adresinden erişilmiştir.

Türkiye Cumhuriyeti Dışişleri Bakanlığı. (t.y). Temel dış politika konulan. (14.07.2020) tarihinde http://www.mfa.gov.tr/turkiye nin-cok-tarafli-ulastirma-politikasi.tr.mfa adresinden erişilmiştir.

Türkiye hızlı tren ağlarıyla donatılıyor. (2018). Akşam, (25.06.2020) tarihinde https://www.aksam.com.tr/guncel/turkiye-hizli-tren-aglariyla-donatiliyor/haber-777002 adresinden erişilmiştir.

Türkiye'ye Doğrudan Çin Yatırımları İvme Kazandı. (2018). Bloomber HT. (15.07.2020) tarihinde https://businessht.bloomberght.com/piyasalar/haber/1870596-turkiye-ye-dogrudan-cin-yatirimlari-ivme-kazandi adresinden erişilmiştir.

UTIKKAD. (2012). Bir bakışta: Bakü-Tiflis-Kars demiryolu projesi. (28.07.2020) tarihinde https://www.utikad.org.tr/Detay/Sektor-Haberleri/10325/bir-bakista:-bakutiflis-kars-demiryolu-projesi adresinden erişilmiştir.

Üzümcü, A., ve Akdeniz, S. (2014). Yeni İpek Yolu: TRACECA ve Bakü-Tiflis-Kars Demiryolu projesi. Avrasya Etüdleri, 45(1). 11-39.

Vakulchuk, R. ve Overland, I. (2019). China's Belt and road mitiative through the lens of Central Asia. (Der. In Fanny M. Cheung- Ying-yi Hong), Regional Connection Under The Belt and Road Initiative, Routledge: London.

Valiyev, A. (2015). Can Azerbaijan revive the silk road?, PONARS Eurasia Policy Memo 382, (21.07.2020) tarihinde https://www.ponarseurasia.org/sites/default/files/policy-memos-pdf/Pepm382 Valiyev Aug2015.pdf adresinden erişilmiştir.

Xınhua, Turkey expects China's investment in high speed railway Project. (2014). Shanigai Daily, (17.07.2020) tarihinde https://archive.shine.cn/article/article xinhua.aspx?id=210280 adresinden erişilmiştir.

Yan, D. (2017). China's Strategy in the Caucasus, 21.12.2020 tarihinde https://kafkassam.com/chinas-strategy-in-the-caucasus.html adresinden erişilmiştir. 
Y1lmaz, S. (2019). Bir kuşak bir yol projesi: Kavramlar, aktörler, uygulamalar. Ankara:Astana Yayınları.

\section{Kaynakça Bilgisi / Citation Information}

Yılmaz, S. (2020). Bir kuşak bir yol projesinin Azerbaycan, Kazakistan ve Türkiye'ye etkisi. OPUS-Uluslararası Toplum Araştırmaları Dergisi, 16(32), 5274-5301. DOI: 10.26466/opus.774919 